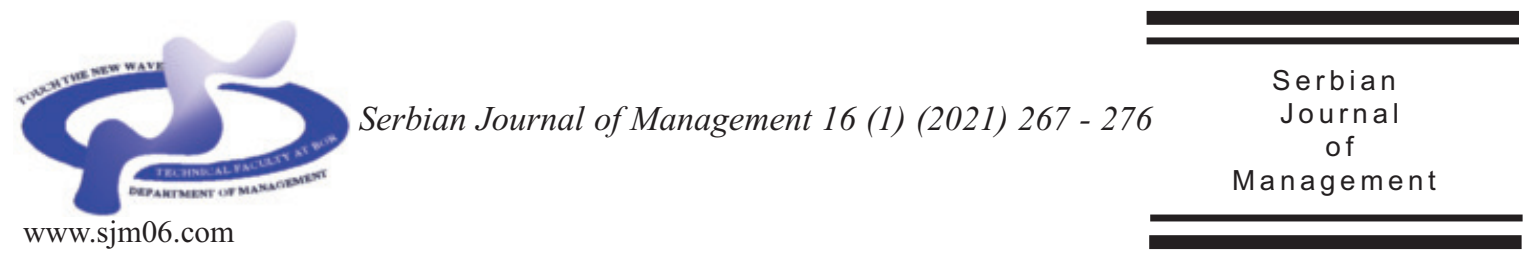

\title{
UTILIZATION OF SHOP FLOOR MANAGEMENT AS A TOOL FOR COMMUNICATION AND KNOWLEDGE SHARING IN THE FRAMEWORK OF LEAN LOGISTICS - A CASE STUDY
}

\author{
Petra Benyahya* and Lucie Macurová \\ Tomas Bata University in Zlin, Faculty of Management and Economics, Mostní 5139 \\ 76001 Zlin, Czech Republic
}

(Received 20 March 2020; accepted 27 November 2020)

\begin{abstract}
The study investigates whether establishing of the shopfloor management in the company is beneficial for the company or not even in difficult conditions (food production with BRC standards of production, presence of foreigners, agency employees). A qualitative research based on detailed long-term observation the real process of planning and establishing the shopfloor management in the company was used, as well as interviews with industrial engineers, first line managers, blue-collar workers, and shopfloor management practitioners. The company was chosen for this case study on purpose. The findings say it was good to establish SFM in the company. In spite of obstacles, the utilization of machines increased by $20 \%$ and one machine (out of 12) could be sold due to redundancy. The need for human capital decreased, the number of scraps decreased, and the cooperation improved.
\end{abstract}

Keywords: shopfloor management, cooperation, communication, lean culture tool

\section{INTRODUCTION}

Studies as Moyano-Fuentes and Sacristán-Díaz (2012), Bortolotti et al. (2015), de Vries et al. (2010), Chi Anh et al. (2013) show positive impact of shopfloor management on a firm's operational performance - mainly reduced process variability, scraps, rework time and increased process flexibility.

\footnotetext{
* Corresponding author: benyahya@utb.cz
}

DOI: $10.5937 /$ sjm16-25783
Despite this, it is still not clear whether the SFM is beneficial also for the companies under difficult internal conditions, such as companies in food production with BRC standards, companies with number of foreigners, companies with agency employees. This means that the topic needs further exploration.

The aim of this study is to investigate whether establishing of the shopfloor 
management in the company is beneficial for the company or not even under difficult internal conditions (food production with BRC standards of production, presence of foreigners, agency employees).

There might be so many detailed elements that can affect the quality of establishing the SFM, so qualitative research approach in the form of a case study was chosen. The company for case study was chosen in order to show a case of company where many obstacles in establishing the SFM might occur. It is a family company, medium-sized company, food production with BRC (British Retail Consortium) standards of production, company with agency employees, with foreign employees from different countries, company situated in the post-communist country, where SFM was established in the period of low unemployment rate. All these characteristics might cause possible obstacles in SFM establishing.

The paper is structured as follows: First, theoretical background is presented, then the research design is explained. After that, results, discussion, and conclusion are presented.

\section{THEORETICAL BACKGROUND}

\subsection{Shopfloor management}

The term "shopfloor management" is mentioned in many research papers, such as Riegger (2011), Uwe Dombrowski et al. (2014), but still the literature is not rich in understanding its specifics (Hertle et al., 2015). Suzaki (1993) defines shopfloor management as practicing the three focuses: gemba (real place), genbutsu (real thing) and genjitsu (real fact). Shopfloor management focusses on Gemba (Japanese word for shopfloor), because this is the place where value is created (Suzaki, 1993). The focus on genbutsu requires all associates to understand the nature of problems rather than relying on documented information (Hanenkamp, 2013). Focus on genjitsu implies that the connections between the current problems and their final root causes have been mapped based on valid and consistent data (Hanenkamp, 2013).

SFM contains six main areas (Hertle et al., 2015): (1) Empowering every single employee and utilizing their full potential, (2) presence of leading personnel on the shopfloor, (3) using various concepts of visualization, (4) introducing new organization forms like mini-factories, (5) fostering the application of improvement and problem solving processes, (6) facilitating competency development on the shopfloor.

Objectives of SFM are defined as following: (1) Development of leading personnel to methodical coaches (Peters, 2009; Hölzl, 2014), (2) utilization of workers' complete potential, (Riegger, 2011; Kudernatsch, 2013), (3) sustainable support of other lean principles (Kudernatsch, 2013), (4) optimization of KPIs (Riegger, 2011).

For our purposes, SFM appropriately combines the methods of visual management, teamwork, time management, and rapid troubleshooting into an effective form of business process management.

\subsection{Elements of Shopfloor Management}

Stöhr (2012) wrote following elements of Shopfloor Management: (a) Visualization. Minimal obstacles for material-flow and information-flow. No problem must remain hidden. If everything is $\mathrm{OK}$, it can be a sign of lack of ability to see problems. This already is a problem. (b) Go to the 
workplace. Regular supervision of plan fulfilling/requirements fulfilling at the workplace. Do not believe the illusion that you can manage processes from your office. (c) Develop people's abilities. Teach people to see what you see. Teach people to see problems even if you are not there, so that they want to solve these problems. (d) Problem-solving. Help people responsible for the process to resolve the problem. Remove obstacles that obstruct people from effective solving of problems in processes for which they are responsible. If you solve the problem, the potential of your people does not develop.

\subsection{Levels of shopfloor management maturity}

Peters (2009) distinguish three levels of SFM maturity. On the first level it is reacted quickly to process failures, i.e. the problems have already occurred (e.g. the breakdown of a single machine or a section of the production line). On the second level it is emphasized the preventative problem avoidance, i.e. potential sources of risks are systematically monitored and actions are put in place as necessary. On the third level, deviations from standards are closely monitored to prevent the occurrence of problems, implying that root cause and effect is well understood (Hanenkamp, 2013).

\subsection{Proved benefits of hopfloor Management}

de Vries et al. (2010) and Chi Anh et al. (2013) found out the positive effect of shopfloor communication on the implementation of process management practices and the resultant quality performance.
If management of a company is the first who start working as proper SFM, a sense of responsibility emerges very quickly at other levels, a sense of urgency, people begin to solve problems in a structured way, people follow the actions through to the end in agreed deadlines, people learn to communicate better (Myška, 2017). This will lead to a significant decrease in the problems and operational activities of the managers.

The empirical study (Moyano-Fuentes and Sacristán-Díaz, 2012) show positive impact on a firm's operational performance mainly ,reducing process variability, scraps, and rework time, which in turn reduce production costs and lead times and increase process flexibility and quality conformance" (Bortolotti et al., 2015).

When team members share their knowledge, their team was better able to meet project goals, achieve quality, meet customers' expectations and achieve efficiency (Hong et al., 2004).

Teamwork is needed, but cross-functional teams bring other benefits (Oláh at al., 2017). It was proved, that cross-functional teams reduce supervision costs and allow interdependent tasks to be completed (Leach et al., 2005).

\section{RESEARCH OBJECTIVE, METHODOLOGY AND DATA}

The aim of this study is to investigate whether establishing of the shopfloor management in the company is beneficial for the company or not even under difficult internal conditions (food production with BRC standards of production, presence of foreigners, agency employees). As the most suitable method for our aim was chosen a case study. 
The company was chosen in order to show a case of company where many obstacles in establishing the SFM might occur. It is a family company, medium-sized company with 416 registered employees, food production with BRC (British Retail Consortium) standards of production, company with own employees and agency employees, with foreign employees from different countries, company situated in the post-communist country, where SFM was established in the period of very low unemployment (2.2\%). All these characteristics might cause possible obstacles in SFM establishing.

The chosen company is 1td.-limited company. EBIT was $249255000 \mathrm{CZK}$, EVA 151735734 CZK. ROA is $13.04 \%$ and return on sales are significantly higher than the industry average. Sales per employee are higher than is usually claimed. Indicated proportion of engaged employees is $42.14 \%$ (high). The return on investment in human capital is 1.12 (relatively low). The overall performance of the organization is very good. The economic situation might not affect the process of SFM establishment success.

In 2017, the company decided to accelerate the way of solving problems arising in production by implementing SFM. The data for this study were gathered through detailed long-term (2.5 years long) observation the real process of planning and establishing the SFM directly in the company. Unstructured interviews with 3 industrial engineers from the company were used, they were responsible for the SFM implementation in the company. They were asked every half a year for their practical experience with SFH establishment in the company (process of SFM establishment preparation, benefits of SFM establishment in the company, results and impacts of SFM on the production efficiency, problems with SFM in every phase - from establishment to feedback after 2 years of running). Many informal unstructured interviews with first line managers from the company were used as well. They participate and lead SF meetings and manage the production. They were asked topics related to benefits of SFM establishment in the company, their opinions about problems with SFM during 2 years of running SFM in the company. Many informal unstructured interviews with bluecollar workers from the company were used as well. Blue-collar workers were asked themes such as benefits of SFM establishment in the company, their opinions about problems with SFM during 2 years of running SFM in the company. Consultations with 2 SFM practitioners from 2 different production companies (with practical experience with SFM establishment) were used too. All the interviews were recorded, written down and coded to make a text analysis. All the interviews and consultations were analyzed; we were looking for similarities in the responses. Gathering information related to the production efficiency was used, as well as gathering information related to the financial results of the company from annual reports.

\section{REREARCH RESULTS}

\subsection{Noise during SF meetings}

It is very noisy production (80-105 decibels). During SF meeting participants hardly understand each other. To stop the machines is not solution, after starting the machine again next 10 minutes the machine produces poor quality outputs. The workers 
did not complained that they do not listen, they even confirmed that they listened what is their task. After 3 months, it was decided to use microphones and repro for SF meetings. At the beginning, the employees resisted using the microphones, they were even laughing if someone should use the microphone that the person is like a TV star, but very soon they realized that it is good for them. The moderators protect their vocal cords more and the quality of provided information improved.

\subsection{Problem solving}

As there are 3 production centers in the company, and their SF meetings take part at the same time, it was impossible for process engineer to visit SF meeting in all centers in one day. The process engineer decided to visit first day first center, second day the second center and third day the third center to participate at SF meeting. When applying this circle, the process engineer found out that when one center faces some problem, they find some solution, but because the employees from different centers do not meet each other across the centers, and they do not have many possibilities to meet each other and communicate together. It happened that few weeks later another center faced the same problem as the first center before. There was no knowledge sharing among different centers and employees were wasting time to solve problems, which were already solved at another center.

Now the company tries to establish some system of knowledge sharing among different production centers. It is still at the beginning, so they use the assistant boards where the employees place the photos of nonconformities from the processes and mark with red liner the mistakes, they write there also the description of the problem, who is solving the problem, how the problem was solved and the number of problem. All these is visualized on the board all the time so anybody from different production center can come and see it, and later contact the person who was solving the problem. This information is archived in a paper form in plastic pocket down the SF board. According to the number of problem you can find the paper with problem description and solution, or you can just browse the pocket and look for some problem solution. Now it was suggested that the photos of nonconformities with described problem should be visualized on big screens in production halls. They already had big screens in production halls where some information is published - such as that today the HR department is closed, the lunch will start to serve 30 minutes later today etc. in such a loop so employees see it many times per working shift. People are reading less and less, they do not want to read (except information about their wage) but to see photos is $\mathrm{OK}$.

\subsection{System of priorities}

In the part of SF board where the day tasks are, there are number of particular machines and their tasks. The company started to apply the system of priorities. It means that the tasks get some number showing how important is the specific task for the company. Green arrows indicate that this task is a priority; the product must be delivered to the customer very soon. Red arrows indicate that the machine is in machine shutdown. Here SF board helped to harmonize the planned production, customers' demands and maintenance. Before SFM, it happened often that the maintenance man chose a machine, because 
he did not maintenance this machine for a long time. He stopped production at this machine and did not care that the machine produces priority production that the customer needs very soon and that cannot be produced by any other machine. The planner noticed this change usually after the lunch, when he went along the machine for his lunch and was very surprised why the machine is not working when customer's vehicle is waiting outside on the ramp for the last two euro-pallets.

Now the maintenance-man is present at SF meetings so they can plan maintenance at those machines that are in machine shutdown. In case of any problem at machine with high priority, it is their obligation to repair the priority machine. The company set to have not more than 3 priority machines. If priority machine is out of order, the production can be done on spare machine (with a mold compatible with priority machine). On spare machine is planned such production, that can be stopped in case of problems at priority machine.

\subsection{Problems related to foreign workers and recruitment agency}

Due to unemployment rate about $2.3 \%$, the company hires employees though recruitment and selection agency. About $10 \%$ of all company employees are agency employees, most of them foreigners, especially Slovaks, Ukrainians, Hungarians, Romanians and Creoles. Some language barrier problem occurred. During morning and afternoon shifts, a language interpreter is present in case there is a new employee. If there is not any new employee, or when you move one employee to work on another machine, or at night shifts there was not any possibility to speak with interpreter.
Furthermore, when a foreign employee had and injury, he said that he did not know that he should not put his fingers at some place. Although there are pictograms everywhere sticked on the machines, he said that he did not understand the pictograms.

This problem was partly caused by the recruitment and selection agency, because according to the contract, the recruitment and selection agency is obligated to inform agency employees about the work, all the risks at workplace, how to behave according to the health and safety regulations and at BRC operation. However, the recruitment agency did not do that.

The company prepared all the paper forms in 3 languages: Czech, Ukrainian and Hungarian. They started with translation of work procedures with detailed photo instructions. They also placed short written warnings and instruction directly on the machines. Down the machines there are folds with photos and written detailed safety instructions in three languages and in the fold, there is also telephone number for the interpreters in all the used languages. The employees signed they cannot continue in working process without understanding.

\subsection{Problems related to BRC production}

There is used white board but the process engineers want to replace the SF board with a digital board for these reasons: 1) Some operators write unreadable. 2) In this BRC production, the temperature is very high; the liners' ink flows down, this contamination of BRC production must be disinfected. 3) The liners should be kept in a right position point down, otherwise they got dry very quickly. The costs for the liner are very high. They flow down, they get lost, they are being 
stolen. 4) Employees were reclined with their back on the SF board and erased the written text when discussing. So later every paper on boar had to be laminated info a transparent foil and sticked to the magnetic tape on the reverse. 5) Lamination is also used for prevention to splashing out the text due to high humidity in the production. 6) It is complicated to fill in some paper-form with using the wider liner. If you keep there a pen that is thinner, it flows down the ink and the production is contaminated. Furthermore, it cannot be a regular pen, but more expensive special BRC pen with metal inside (in case you lost it in production, the detector of metal can be used to find it. However, even such BRC pen flows down. When an operator steps into the ink and makes about 5 footprints, all the production must be stopped due to BRC production rules. 7) BRC production also means that anything that could fall down into the production cannot be at the workplace. So magnetic pieces smaller than $10 \mathrm{~cm}$ cannot be there, although if they fall down into the product, the detector of metal can be used to find them. Little bit bigger pieces should be in reflexive colors to be able to find them if they fall down. 8) The space of board is limited. The new digital touchy SF board would solve all these problems.

\subsection{Benefits of SFM for the company}

Communication and collaboration has improved. Employees were more involved. The feedback accelerated. The competence of the staff was extended, they take the responsibility for problem solving. SFM help to solve problems in real time and location.

Due to well-chosen KPIs (Key Performance Indicators) for monitoring performance and problem detection that
SFM enabled, the results in the chosen company were following: (1) Reduced downtime (and related saving) - due to the lack of material or due to the lack of work in progress, but also due to orders on machines or preventive maintenance of machines. (2) Rationalization of changing the type and preventive maintenance plans for machines (and related saving). (3) Use of order prioritization in accordance with production planning on the production machines. (4) Rationalization in planning the use of human capital and machinery. (5) Reduction of nonconformity production.

The utilization of machines increased by 20\%. From 12 machines in the production, one machine was saved (unused) and sold due to the SFM establishment. The need for human capital also decreased. Unfortunately, precise quantification of reached benefits of shopfloor establishment the company does not want to publish due to the business strategy secret.

\section{DISCUSSION}

If we compare our results with other authors, it corresponds. de Vries et al. (2010) and Chi Anh et al. (2013) found out positive effects of shopfloor, the same we found out in our study. Moyano-Fuentes and SacristánDíaz (2012) show reduction of process variability, scraps, rework time, and production costs. The same results occurred in our study.

de Vries et al. (2010) claim that process control requires the information-intensive environment. Myška (2017) wrote that by SFM people communicate better. The same was shown in our case.

Duarte et al. (2017) defined 4 barriers to innovation: economic factors, knowledge 
factors, market factors and reasons to innovate. Among knowledge factors, the highest ranked barrier was lack of qualified personnel (Hvolkova et al., 2019). In our study too.

\section{CONCLUSION}

Of course, every company is different, and problems with SFM implementation can vary. In spite of this, we chose this particular case very carefully. The company and methods of research were chosen with the aim to show the most typical key moments in the process of SFM planning and implementation.

All this case study, detailed long-term observation of the real process of establishing the SFM directly in the company, as well as interviews with industrial engineers from the company, first line managers and blue-collar workers, and consultations with SFM practitioners from different production companies indicate that although there are many key moments on the way of SFM implementation, that can affect the success of implementation, SFM is useful tool of establishing lean culture, as well as creating the knowledge-sharing culture due to the improving of cooperation. This case study proved that SFM dominates benefits.

\section{Acknowledgements}

This contribution was written with the support of the internal TBU project $\mathrm{RO} / 2016 / 07$, “The improvement of organizations' performance through human capital management.

\title{
КОРИШЋЕЊЕ УПРАВЉАҢА ПОГОНИМА КАО СРЕДСТВО ЗА КОМУНИКАЦИЈУ И РАЗМЕНУ ЗНАњА У ОКВИРУ "LEAN" ЛОГИСТИКЕ - СТУДИЈА СЛУЧАЈА
}

\author{
Petra Benyahya, Lucie Macurová
}

\section{Извод}

Студија истражује да ли је увођење управљања погонима (СФМ) у предузећу корисно за компанију или није чак и у тешким условима (производња хране са БРЦ стандардима производње, присуство странаца, запослени у агенцијама). Коришћено је квалитативно истраживање засновано на детаљном дугорочном посматрању стварног процеса планирања и успостављања управљања погонима у предузећу, као и интервјуи са индустријским инжењерима, руководиоцима првог нивоа, радницима у погону и практичарима у управљању погонима. Компанија је за ову студију случаја изабрана циљано. Налази кажу да је било добро успоставити СФМ у компанији. Упркос препрекама, искоришћење машина се повећало за 20\% и једна машина (од 12) би могла да се прода због вишка. Потреба за људским капиталом се смањила, број отпада смањио, а сарадња побољшала.

Кључне речи: управљање поговима, сарадња, комуникација, алат за леан културу 


\section{References}

Bortolotti, T., Boscari, S., \& Danese, P. (2015). Successful lean implementation: Organizational culture and soft lean practices. International Journal of Production Economics, 160, 182-201.

Chi Anh, P., Zeng, J., \& Matsui, Y. (2013). Shop-floor communication and process management for quality performance: An empirical analysis of quality management. Management Research Review, 36 (5), 454477.

de Vries, R. E., Bakker-Pieper, A., \& Oostenveld, W. (2010). Leadership = Communication? The Relations of Leaders' Communication Styles with Leadership Styles, Knowledge Sharing and Leadership Outcomes. Journal of Business and Psychology, 25 (3), 367-380.

Uwe, D., Belz, T., \& Jäger, F. (2014). Shopfloor Management in control circuit of the GPS implementation. ZWF Zeitschrift Für Wirtschaftlichen Fabrikbetrieb, 109(12), 20-25. (In German). https://doi.org/10.3139/104.111081

Duarte, F., Madeira, M. J., Moura, D.C., Carvalho, J., \& Moreira, J.R.M. (2017). Barriers to innovation activities as determinants of ongoing activities or abandoned. International Journal of Innovation Science, 9 (3), 244-264.

Hanenkamp, N. (2013). The Process Model for Shop Floor Management Implementation. Advances in Industrial Engineering and Managemen, 2 (1) 40-46.

Hertle, C., Siedelhofer, C., Metternich, J., $\&$ Abele, E. (2015). The next generation shop floor management-how to continuously develop competencies in manufacturing environments. The 23rd International Conference on Production Research, Manila, Philippines, 03.08.2015.
Hölzl, H. (2014). Lead a diverse group. Personalwirtschaft, 5, 45-47. (In German).

Hong, P., Doll, W.J., Nahm, A.Y., \& Li, X. (2004). Knowledge sharing in integrated product development. European Journal of Innovation Management, 7 (2), 102-112.

Hvolkova, L., Klement, L., Klementova, V., \& Kovalova, M. (2019). Barriers Hindering Innovations in Small and Medium-Sized Enterprises. Journal of Competitiveness, 11 (2), 51-67.

Kudernatsch, D. (2013). Anchoring a lean culture in the company. Wissensmanagement, 3, 48-49. (In German).

Leach, D.J., Wall, T.D., Rogelberg, S.G., \& Jackson, P.R. (2005). Team autonomy, performance, and member job strain: Uncovering the teamwork ksa link. Applied Psychology, 54 (1), 1-24.

Moyano-Fuentes, J., \& Sacristán-Díaz, M. (2012). Learning on lean: A review of thinking and research. International Journal of Operations and Production Management, 32 (5), 551-582.

Myška, J. (2017). Shop Floor Management - a great tool for building a lean culture | API Akademie. Úspěch Produktivita \& Inovace v Souvislostech, 2017(1). http://www.e-api.cz/25865n-shopfloor-management-skvely-nastroj-probudovani-stihle-kultury (In Czech).

Oláh J., Szolnok Á., Nagy G., Lengyel P., Popp J. (2017). The Impact of Lean Thinking on Workforce Motivation: A Success Factor at LEGO Manufacturing Ltd. Journal of Competitiveness, 9 (2), 93-109.

Peters, R. (2009). Shopfloor Management: Leadership at the place of value creation (1st ed.). Ludwigsburg, Germany: LOG_X. (In German).

Riegger, M. (2011). Big leap in quality through shopfloor management]. 


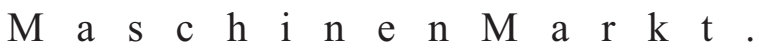
https://www.maschinenmarkt.vogel.de/gross er-qualitaets sprung-durch-shopfloormanagement-a-321678/ (In German).

Stöhr, T. (2012). Shop Floor Management-PDF. Akademie Produktivity a Inovací, s.r.o. https://docplayer.cz/1128256-Shop-floormanagement.html (In Czech).

Suzaki, K. (1993). New Shop Floor Management: Empowering People for Continuous Improvement. New York, USA: Simon and Schuster. 